\title{
Phytotherapeutic Drugs used by the Tribes of Amarkantak District Anuppur, Central India
}

\author{
Ishwar Chandra Prana \\ Department of Botany, Pt. S.N.S. Govt. P.G College, Shahdol- 484001 India
}

\begin{abstract}
The present paper deals with 30 plants species which are conserved by the tribes of Amarkantak district Anuppur Madhya Pradesh. Due to destruction of habitat, biotic interference and indiscriminate exploitation of natural plants, many valuable plant species of this area are fast disappearing. Aboriginals conserve these species by faiths, taboos and religious aspects.
\end{abstract}

Keywords: Phytotherapeutic,Tribes , Amarkantak, Anuppur

\section{Introduction}

Amarkantak plateau is one of the important tourists place in district Anuppur, Madhya Pradesh . This district is located in the central part of India. It is lying between $23^{\circ} 15^{\prime}$ to $24^{\circ} \mathrm{N}$ Latitude and $81^{\circ} 0^{\prime}$ ' to $81^{\circ} 45^{\prime} \mathrm{E}$ longitude. The total area of $3701 \mathrm{Sq}$. Km extends $80 \mathrm{Km}$. from east to west and $70 \mathrm{Km}$. from North to South. Several tribalsasGond, Kondar, Kol, Baiga ,Bharia , etc. are maintaining their culture and traditions since these cultures are influenced by scientific and economic changes, it is therefore, essential to study and conserve them before they become extinct. Madhya Pradesh still has the aboriginal tribals living in the forest as well as in the remote villages inhabited by so called higher castes. Since they are distributed mostly in the areas previously occupied by thick forest, they have learnt to use these habitats better for their living.(Figure 1)

A survey of literature indicates that Dwivedi (2003), Jain $(1963,1997)$, Khare (2001) , Prajapati and Khare(2004), Saxena and Tripathi $(1989,1990)$, Shah and Singh (1990) and Singh et al (2004) has made important contribution in this field.

The tribals do not have any well defined conservation strategy of the kind we understand in modern terms. But they do conserve plants that are medicinally, economically, socially and culturally significant to them. Their mode of conservation depends on faith and tradition.

\section{Materials and Methods}

For the ethnobotanical study plant human interaction has to be observed carefully in the dynamic ecosystem in which they exist. The plants were collected by the investigator from the different study sites of Anuppur district during 2002-2003 by extensive field work . The queries were made as per plan suggested by Jain and Goel (1987) and the preservation methods were followed as prescribed by Agrawal(1983) and Ahirwar (2011).

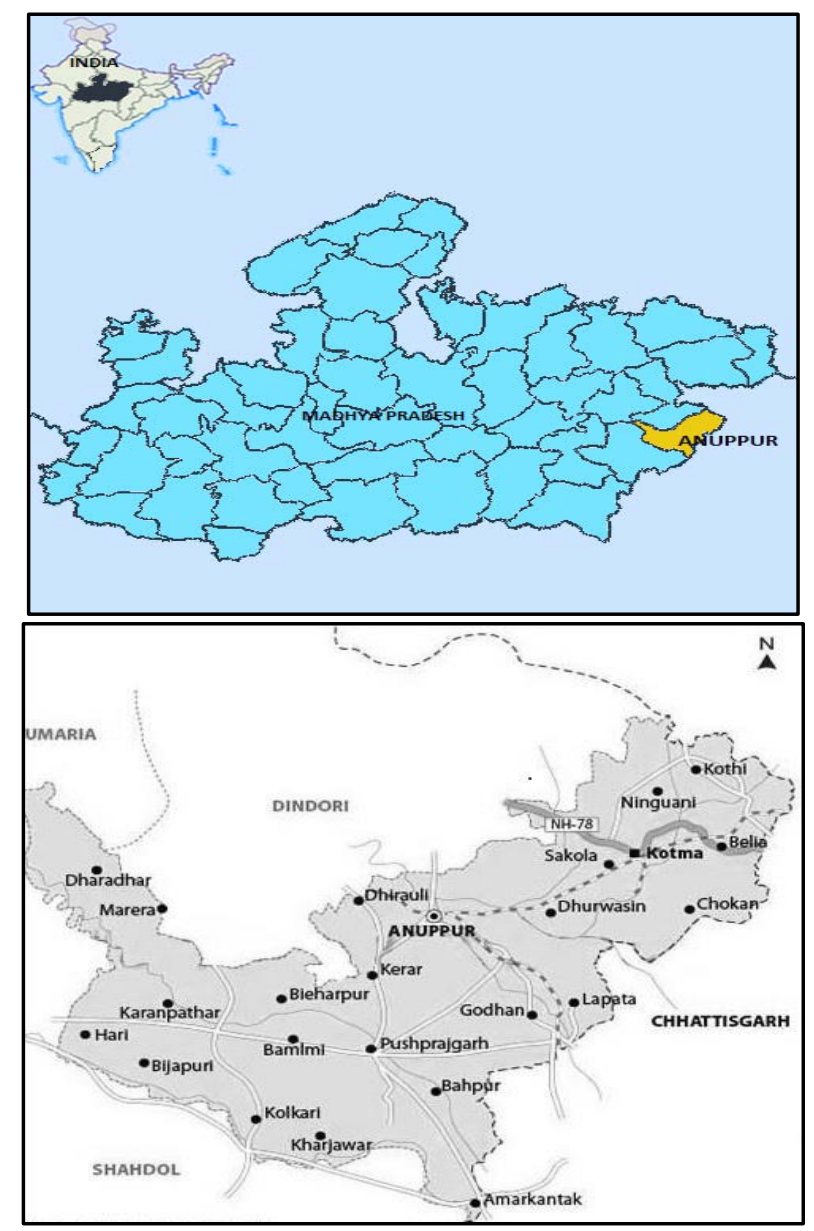

Figure 1: Location Map of Madhya Pradesh and study site District Anuppur 


\section{International Journal of Science and Research (IJSR) \\ ISSN (Online): 2319-7064 \\ Index Copernicus Value (2013): 6.14 | Impact Factor (2015): 6.391}

Table 1: Phytotherapeuticdrugs used by the Tribes of Amarkantak,District Anuppur, Central India

\begin{tabular}{|c|c|c|c|c|}
\hline S.No. & Plant Name ( Local Name ) & Family & Plant part uses & Reason for Conservations \\
\hline 1. & Achyranthusaspera L.(Chirchita) & Amaranthaceae & Root and leaves & $\begin{array}{c}\text { Roots are leaves are used in } \\
\text { medicine. }\end{array}$ \\
\hline 2. & Adina cordifoliaBenth.\& Hook (Haldu) & Rubiaceae & Wood & The wood is considered auspicious. \\
\hline 3. & Aegle marmelos (L.) Corr.(Bel) & Rutaceae & Leaf & $\begin{array}{c}\text { Sacred plant, the leaves are used to } \\
\text { worship' Lord Shiva'. }\end{array}$ \\
\hline 4. & $\begin{array}{ll}\text { squamosa } & \text { (Sitaphal) }\end{array}$ & Annonaceae & Fruit, seed & For fruits and medicine. \\
\hline 5. & $\begin{array}{l}\text { Anthocephaluschinensis (Lamk. } \\
\text { )Rich.(Kadam). }\end{array}$ & Rubiaceae & Whole plant & Sacred plant, fruits are edible. \\
\hline 6. & AzadirachtaindicaJuss.(Neem) & Meliaceae & Leaf & $\begin{array}{c}\text { Plant is an abode of 'Marhi Mata' ( } \\
\text { The Goddess of small pox ) Leaves } \\
\text { are used in medicines and pest } \\
\text { control. }\end{array}$ \\
\hline 7. & BoswelliaserrataColebr.(Salaiya) & Burseraceae & Wood & $\begin{array}{c}\text { The poles of wood are considered } \\
\text { auspicious for wedding place. }\end{array}$ \\
\hline 8. & Buchananialanzan Spr.(Char) & Anacardiaceae & Fruits and seeds & For fruits and seeds. \\
\hline 9. & Butea monosperma (Lamk.) Taub. (Palas) & Papilionaceae & Leaves and flowers & $\begin{array}{l}\text { Leaves are used for thatches, and } \\
\text { the flowers are used to worship } \\
\text { 'Lord Jagannath. }\end{array}$ \\
\hline 10. & Calotropisprocera Br.(Madar) & Asclepiadaceae & Flowers and fruits & $\begin{array}{l}\text { The flowers and fruits are used to } \\
\text { worship 'Lord Shiva'. }\end{array}$ \\
\hline 11. & ErythrinasuberosaRoxb.(Handua) & Papilionaceae & Wood & $\begin{array}{l}\text { The wood is considered auspicious } \\
\text { for wedding place. }\end{array}$ \\
\hline 12. & Ficusbengalenis L.(Bar) & Moraceae & Whole plant & $\begin{array}{l}\text { Sacred plant worshiped on 'Bara } \\
\text { Barsat' festival. }\end{array}$ \\
\hline 13. & Ficusreligiosa L.(Pipal) & Moraceae & Whole plant & $\begin{array}{l}\text { The plant is considered on abode of } \\
\text { 'Barsat 'festival. }\end{array}$ \\
\hline 14. & Gymnemasylevestre( Retz.) R.Br.( Gurmar) & Asclepiadaceae & Leaf & The leaves are used in medicine . \\
\hline 15. & Holarrhenaantidysenterica Wall.( Dudhi) & Apocynaceae & Bark & The bark is used for medicine. \\
\hline 16. & $\begin{array}{l}\text { Holopteleaintergrifolia } \\
\text { (Roxb.)Planch.(Chirol) }\end{array}$ & Ulmaceae & Leaf and Bark & $\begin{array}{l}\text { Leaves are used as fish poison and } \\
\text { bark is used in medicine. }\end{array}$ \\
\hline 17. & Lawsoniainermis L. (Menhdi) & Lythraceae & Leaf & The leaves are used for dye. \\
\hline 18. & Madhucalongifolia (Koen.)Mac. Br.(Mahua) & Sapotaceae & Whole plant & $\begin{array}{l}\text { Sacred plant, flowers used for } \\
\text { liquor, and the wood is considered } \\
\text { auspicious. }\end{array}$ \\
\hline 19. & Mangiferaindica L.(Aam) & Anacardiaceae & Whole plant & $\begin{array}{l}\text { For wood, leaves and fruits. The } \\
\text { inflorences are offered to 'Lord } \\
\text { Shiva' at Mahashivratri festival. }\end{array}$ \\
\hline 20. & Ocimum sanctum L. (Tulsi) & Lamiaceae & Whole plant & $\begin{array}{l}\text { Sacred plant, worshiped by girls for } \\
\text { good groom. }\end{array}$ \\
\hline 21. & Phoenix sylvestrisRoxb. (Khajri) & Araceae & Leaf, fruit & $\begin{array}{l}\text { The fruits are edible and leaves are } \\
\text { used to make headgear and brooms. }\end{array}$ \\
\hline 22. & Emblicaofficinalis L.(Amla) & Euphorbiaceae & Whole plant & $\begin{array}{l}\text { Sacred plant, worshipped on } \\
\text { 'AkshayaNavmi' , fruits are eaten } \\
\text { and used in medicine. }\end{array}$ \\
\hline 23. & SterculiaurensRoxb.(Kullu) & Sterculiaceae & Whole plant & $\begin{array}{l}\text { The plant is conserved for gum, } \\
\text { wood and medicine use. }\end{array}$ \\
\hline 24. & SterculiavillosaRoxb.(Udar) & Sterculiaceae & Root & The root is taken as a medicine. \\
\hline 25. & Syzygiumcuminii (L) Skeels.(Jamun) & Myrtaceae & Fruits & Fruits are edible. \\
\hline 26. & $\begin{array}{l}\text { Terminalia arjuna (Roxb.ex. DC.)Wt. \&Arn. } \\
\text { (Kahwa) }\end{array}$ & Combretaceae & Whole plant & $\begin{array}{l}\text { Sacred plant, bark is used in } \\
\text { medicine. }\end{array}$ \\
\hline 27. & Terminalia bellerica (Gaertn.) Roxb.(Bahera) & Combretaceae & Fruits & $\begin{array}{l}\text { The fruits are eaten with of Amla as } \\
\text { a medicine. }\end{array}$ \\
\hline 28. & Terminalia chebula Retz.(Harra) & Combretaceae & Fruits & $\begin{array}{l}\text { Roasted fruits are eaten as a } \\
\text { medicine. }\end{array}$ \\
\hline 29. & $\begin{array}{c}\text { Terminalia tomentosa } \\
\text { Wt.\& Arm(Saja) }\end{array}$ & Combretaceae & Whole plant & $\begin{array}{l}\text { Sacred plant , dwelling place of } \\
\text { 'Bara Dev'. }\end{array}$ \\
\hline 30. & Woodfordiafruiticosa (L.) Kurz.(Dhwai) & Lythraceae & Flowers & Flowers used in medicine. \\
\hline
\end{tabular}




\section{Results and Discussion}

During study period is reported with 30 plant species, which are conserved by the tribals of Anuppur district for obvious reasons. These tribals organise various occasions and worship plants time to propitiate their gods and goddess. These traditions encouraged us to know their beliefs and ethnobotanical importance behind it. The botanical name of plants are alphabetically arranged, followed by their local name . All the data obtained as a sequence of present study has been reported.(Table 1)

\section{Acknowledgement}

The authors are thankful to tribal of this district in providing information about the plant species conserved by them. We express our gratitude to the Principal of Govt. P.G. College, Shahdol (M.P.) for helpful suggestions and encouragement.

\section{References}

[1] Agrawal, V.S.(1983). Perspective in Botanical Museum with species reference to India . Today and Tomorrow, New Delhi.

[2] Ahirwar, R.K. "Ethno medicinal plants studies in Jaitpur Forest Range of Shahdol District, Central India." Ad. plantSci 24 (2011): 681-684.

[3] Ahirwar, Ramesh Kumar and Girja, Kumar Singh (2011) Someanti diabetic plants from Dindori District of Madhya Pradesh (India). Ind. J. Appl. pure Bio.26 (2) 269-271.

[4] Dwivedi ,S.N.(2003) . Etgnobotanical studies and conservational strategies of wild and natural resources of Rewa district of Madhya Pradesh ,J .Econ. Taxon.Bot..27.

[5] Jain , S.K.(1963), Observations on ethnobotany of the tribals of Madhya Pradesh . Vanyajati11(4): 177-183.

[6] Jain , S.K. and A.K. Goel(1987) . Problem for field work . P. 171-183. In manual of ehthnobotany . Ed. S.K. Jain, Scientific publisher( India) Jodhpur.

[7] Khare, R.K. (2001) Study of ethnobotany among the tribals of Panna district with species reference to biodiversity. Ph. D. Thesis A.P.S. Univ. Rewa (M.P.)

[8] Prajapati , P.L. and P.K. Khare (2004) . Medicinal plants used by tribals of Panna district Madhya Pradesh (India) Plant Archives.4:113-115.

[9] Saxena , S.K. and J.P. Tripathi(1989). Ethnobotany Bundelkhand I. Medicinal uses of wild trees by tribals inhabitants of Bundelkhandregion .JouEco.Taxono..Bot.14:263-170.

[10] Shah , N.C. and S.C. Singh (1990), Hitherto unreported phytotherapeutical uses of tribals pockets of Madhya Pradesh, India , Ethnobotany, 2 : 91-95. 